\title{
New-onset insulin-dependent diabetes due to nivolumab
}

\author{
Ali A Zaied1, Halis K Akturk², Richard W Joseph³ and Augustine S Lee ${ }^{1}$ \\ Divisions of ${ }^{1}$ Pulmonary and Critical Care Medicine, ${ }^{2}$ Endocrinology, and ${ }^{3} \mathrm{Hematology}$ and Oncology, Mayo Clinic, \\ Jacksonville, Florida, USA
}

Correspondence

should be addressed

to A S Lee

Email

lee.augustine@mayo.edu

\section{Summary}

Nivolumab, a monoclonal antibody against programmed cell death-1 receptor, is increasingly used in advanced cancers. While nivolumab use enhances cancer therapy, it is associated with increased immune-related adverse events. We describe an elderly man who presented in ketoacidosis after receiving nivolumab for metastatic renal cell carcinoma. On presentation, he was hyperpneic and laboratory analyses showed hyperglycemia and anion-gapped metabolic acidosis consistent with diabetic ketoacidosis. No other precipitating factors, besides nivolumab, were identified. Pre-nivolumab blood glucose levels were normal. The patient responded to treatment with intravenous fluids, insulin and electrolyte replacement. He was diagnosed with insulin-dependent autoimmune diabetes mellitus secondary to nivolumab. Although nivolumab was stopped, he continued to require multiple insulin injection therapy till his last follow-up 7 months after presentation. Clinicians need to be alerted to the development of diabetes mellitus and diabetic ketoacidosis in patients receiving nivolumab.

\section{Learning points:}

- Diabetic ketoacidosis should be considered in the differential of patients presenting with metabolic acidosis following treatment with antibodies to programmed cell death-1 receptor (anti-PD-1).

- Autoimmune islet cell damage is the presumed mechanism for how insulin requiring diabetes mellitus can develop de novo following administration of anti-PD-1.

- Because anti-PD-1 works by the activation of T-cells and reduction of 'self-tolerance', other autoimmune disorders are likely to be increasingly recognized with increased use of these agents.

\section{Background}

Understanding how cancer escapes host immune regulation has led to the development of cancer 'immunotherapy'. In particular, antibodies such as nivolumab, targeting and inhibiting programmed cell death 1 receptor (PD-1(PDCD1)), can result in the preferential activation of T-cells with specificity for cancer (1). Multiple trials have already demonstrated significant response rates and improved survival with nivolumab in multiple neoplasms including melanoma $(2,3,4,5,6,7$, $8,9,10,11)$, non-small-cell lung cancer (NSCLC) $(2,3$,
$4,12,13,14,15)$ and renal cell carcinoma (RCC) $(2,3,4$, $16,17)$.

However, inhibition of the PD-1 pathway results in a reduction of 'self-tolerance', with an apparent increase in immune-mediated adverse events (AE). Clinical trials investigating the efficacy of nivolumab in cancers have reported increased rates of autoimmune endocrinopathies, including: hypophysitis $(5,7,8$, $10,11)$, adrenal insufficiency $(4,5,7,10,12)$, thyroid disorders $(2,3,4,5,6,7,8,9,10,11,12,14,15,16,18)$ 
and hyperglycemia $(2,3,4,6,8,15,17)$. We report a patient presenting critically ill with diabetic ketoacidosis (DKA) after receiving nivolumab. In addition, we provide a review of the literature reporting nivolumab-induced diabetes mellitus (DM). Acute care physicians' awareness of the acute complications of these novel therapies is essential for the timely management of these critically ill patients.

\section{Case presentation}

A Caucasian man, in his early seventies, reported to our emergency department with 3 days of dyspnea, abdominal pain, fatigue and polyuria. Symptoms were progressive despite drinking a significant amount of fluids to keep up with his subjective sense of dehydration. He denied fever, chest pain, edema and visual disturbances.

One year earlier, he had undergone radical right nephrectomy and retroperitoneal lymph node dissection for stage IVB metastatic RCC (metastases to mesenteric lymph nodes and peritoneum). He had received 3 cycles of nivolumab, $3 \mathrm{mg} / \mathrm{kg}$ (300 mg, weight: $90 \mathrm{~kg}$ with BMI of 28.4) intravenously every 2 weeks, with his last infusion 10 days prior to his acute presentation. Notably, the patient was not enrolled in a clinical trial.

Other comorbidities were hypertension and chronic kidney disease that did not require renal replacement therapy. He was on lisinopril and aspirin. He had not been on any systemic glucocorticoids. There was no personal or family history of pancreatitis, DM or other autoimmune disorders.

Patient was afebrile and normotensive with a pulse of 88 beats per minute, respiratory rate of 28 breaths per minute and oxygen saturation of $97 \%$ while breathing ambient air. On examination, he was in moderate respiratory distress due to hyperpnea. There was absent breath sounds on the left lung base with dullness to percussion and decreased tactile vocal fremitus. The rest of his examination was unremarkable. Chest radiographs showed small bilateral pleural effusions (left greater than right) but otherwise clear lung fields.

\section{Investigation}

Laboratory analyses (Table 1) showed severe hyperglycemia $(878 \mathrm{mg} / \mathrm{dL})$ and an anion gap metabolic acidosis (anion gap: 21) associated with 'large' serum acetones and urine ketones. Arterial blood gas confirmed a primary metabolic acidosis ( $\mathrm{pH}:$ 7.23, $\mathrm{HCO}_{3}$ : 12) with partial respiratory compensation $\left(\mathrm{PaCO}_{2}: 18\right)$. Multiple pre-admission outpatient fasting blood glucose levels, as recently as two weeks prior to admission, were normal (86-100 mg/ $\mathrm{dL})$, although the HbA1c at admission was increased at 8.4\%. Other metabolic derangements (hyponatremia and hyperkalemia) were related to ketoacidosis. Additional workup for possible acute pancreatitis, acute coronary syndrome or infectious process was unrevealing. A random C-peptide level was low $(0.4 \mathrm{ng} / \mathrm{mL})$ with concomitant blood glucose of $194 \mathrm{mg} / \mathrm{dL}$. Serum for glutamic acid decarboxylase (GAD65) antibody was drawn at the time of the acute presentation, and when it proved negative on follow-up, testing for other less common autoantibodies (IA-2 and IAA) and human leukocyte antigen typing was considered but deferred by the patient and clinical team given unclear management implications (19).

\section{Treatment}

The patient was diagnosed with DKA due to new-onset insulin-dependent autoimmune diabetes secondary to nivolumab. He was treated accordingly with intravenous hydration, insulin drip and electrolyte replacement. Thereafter, all the metabolic disturbances improved with resolution of hyperglycemia and acidemia. However, he continued to require insulin therapy and was subsequently discharged on subcutaneous insulin.

\section{Outcome and follow-up}

On follow-up, restaging computed tomography showed significant disease progression without pancreatic involvement. Nivolumab was stopped and changed to pazopanib (tyrosine kinase inhibitor). Despite remaining off PD-1 antagonists, the patient continued to require multiple daily insulin injections with insulin glargine (15 units twice daily) and aspartate (5 units with meals, weight $76 \mathrm{~kg}$ ) at his last follow-up 7 months after hospital discharge. The patient subsequently died 8 months after his initial presentation due to complications of his metastatic RCC.

\section{Discussion}

Even though GAD65 antibodies were negative, the inappropriately low C-peptide and sudden onset and persistent hyperglycemia with presentation of DKA confirmed insulin-dependent DM. The repeatedly normal pre-nivolumab fasting blood glucose levels suggest the absence of diabetes prior to nivolumab, while the increased $\mathrm{HbA1c}$ at the time of admission suggests more 
Table 1 Laboratory data.

\begin{tabular}{|c|}
\hline Variable \\
\hline Erythrocyte count $\left(\times 10^{12 / L}\right)$ \\
\hline Hematocrit (\%) \\
\hline Hemoglobin $(\mathrm{g} / \mathrm{dL})$ \\
\hline Mean corpuscular volume (fL) \\
\hline White cell count $(\times 109 / \mathrm{L})$ \\
\hline Differential count $(\%)$ \\
\hline Neutrophils \\
\hline Lymphocytes \\
\hline Monocytes \\
\hline Eosinophils \\
\hline Platelet count (×109/L) \\
\hline Sodium (mmol/L) \\
\hline Potassium (mmol/L) \\
\hline Chloride (mmol/L) \\
\hline Bicarbonate (mmol/L) \\
\hline Glucose $(\mathrm{mg} / \mathrm{dL})$ \\
\hline Blood urea nitrogen (mg/dL) \\
\hline Creatinine $(\mathrm{mg} / \mathrm{dL})$ \\
\hline Total protein (g/dL) \\
\hline Albumin $(\mathrm{g} / \mathrm{dL})$ \\
\hline Bilirubin, total (mg/dL) \\
\hline Magnesium (mg/dL) \\
\hline Calcium \\
\hline Alkaline phosphatase (U/L) \\
\hline Alanine aminotransferase (U/L) \\
\hline Aspartate aminotransferase (U/L) \\
\hline Lipase (U/L) \\
\hline Amylase (U/L) \\
\hline Prothrombin time (s) \\
\hline International normalized ration \\
\hline Activated partial thromboplastin time (s) \\
\hline B-type natriuretic peptide \\
\hline Troponin $\mathrm{T}(\mathrm{ng} / \mathrm{mL})$ \\
\hline Thyroid-stimulating hormone (IU/L) \\
\hline Hemoglobin A1C (\%) \\
\hline C-peptide $(\mathrm{ng} / \mathrm{mL})$ \\
\hline Arterial blood gas \\
\hline $\mathrm{pH}$ \\
\hline $\mathrm{PaCO}_{2}(\mathrm{mmHg})$ \\
\hline $\mathrm{PaO}_{2}(\mathrm{mmHg})$ \\
\hline Urine analysis \\
\hline Specific gravity \\
\hline Leukocyte esterase \\
\hline Nitrite \\
\hline $\mathrm{pH}$ \\
\hline Protein (mg/dL) \\
\hline Glucose (g/dL) \\
\hline Bilirubin \\
\hline Urobilinogen \\
\hline Erythrocyte (cell/hpf) \\
\hline White cell (cell/hpf) \\
\hline Acetone blood \\
\hline Lactate $(\mathrm{mmol} / \mathrm{L})$ \\
\hline Ammonia $(\mu \mathrm{mol} / \mathrm{L})$ \\
\hline Glutamic acid decarboxylase (GAD65) antibody (nmol/L) \\
\hline
\end{tabular}

\begin{tabular}{ccc}
\hline Reference range, adult & Result \\
\hline $4.32-5.72$ & 3.3 \\
$38.8-50.0$ & 29.5 \\
$13.5-17.5$ & 9.0 \\
$81.2-95.1$ & 89.4 \\
$3.5-10.5$ &
\end{tabular}

White cell count $(\times 109 / \mathrm{L})$

$3.5-10.5$

20.4

Neutrophils

$\begin{array}{ll}44.4-70.9 & 95.1\end{array}$

$\begin{array}{ll}17.8-41.5 & 0.8\end{array}$

$\begin{array}{ll}4.7-14.8 & 3.7\end{array}$

$1.0-7.0 \quad 0$

$150-450 \quad 522$

$135-145$

$3.6-5.2$

98-107 92

22-29 12

70-100 878

8-24 41

$0.8-1.23 \quad 2.6^{\dagger}$

$6.3-7.9 \quad 6.7$

$3.5-5.0 \quad 3.3$

$\leq 1.2 \quad 0.3$

$1.8-2.5 \quad 2.7$

$\begin{array}{ll}8.9-10.1 & 8.7\end{array}$

45-115 108

$7-55$

8-48 84

$7-60 \quad 118$

26-102 27

$11.6-14.7 \quad 13.1$

$0.8-1.1 \quad 1.0$

22.7-36.1 35.4

$\leq 67 \quad 206$

$0.00-0.10<0.01$

$0.3-4.2$

$<6.5 \quad 8.4$

$\begin{array}{ll}1.1-4.4 & 0.4\end{array}$

$\begin{array}{ll}7.35-7.45 & 7.23\end{array}$

35-45 17.6

80-100 99

002-1.030 1.016

Negative Negative

Negative Negative

$\begin{array}{ll}5.0-8.0 & 5.0\end{array}$

Negative 10

Negative $>1$

Negative Negative

$0-2 \quad<1$

$<1$

Negative Large

$0.9-1.7 \quad 1.4$

$0-30 \quad 18$

$\leq 0.02 \quad 0.00$

${ }^{\dagger}$ Estimated glomerular filtration rate (eGFR) was $25 \mathrm{~mL} / \mathrm{min} / 1.73 \mathrm{~m}^{2}$; baseline $\mathrm{Cr}$ is $1.8-2.2 \mathrm{mg} / \mathrm{dL}$. 

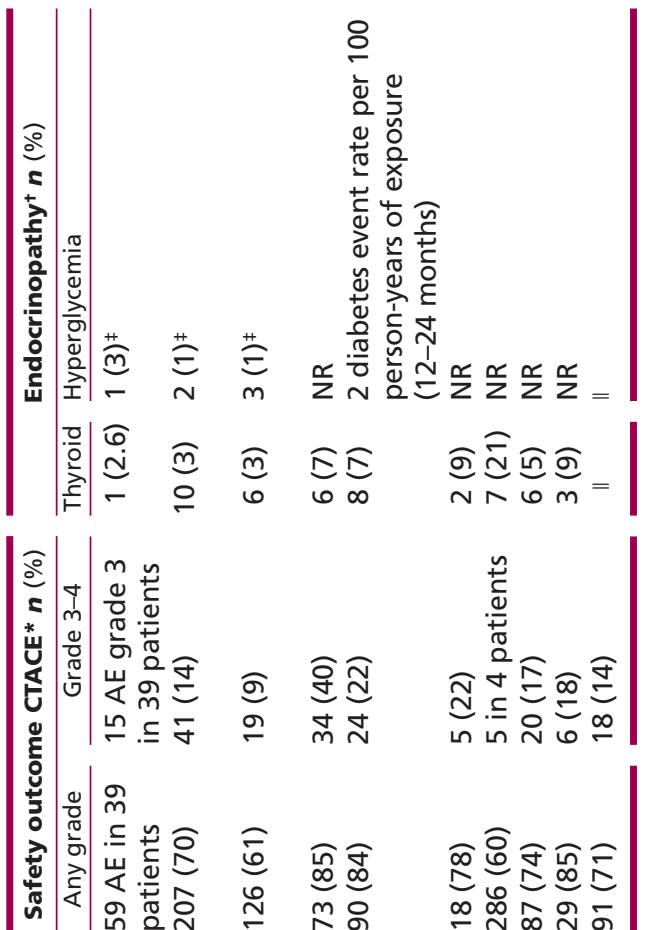

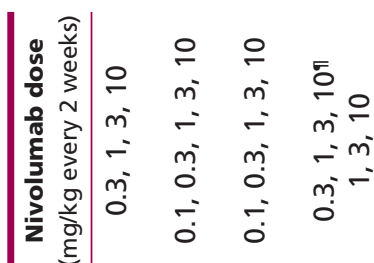

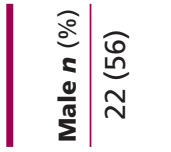

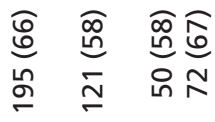

|
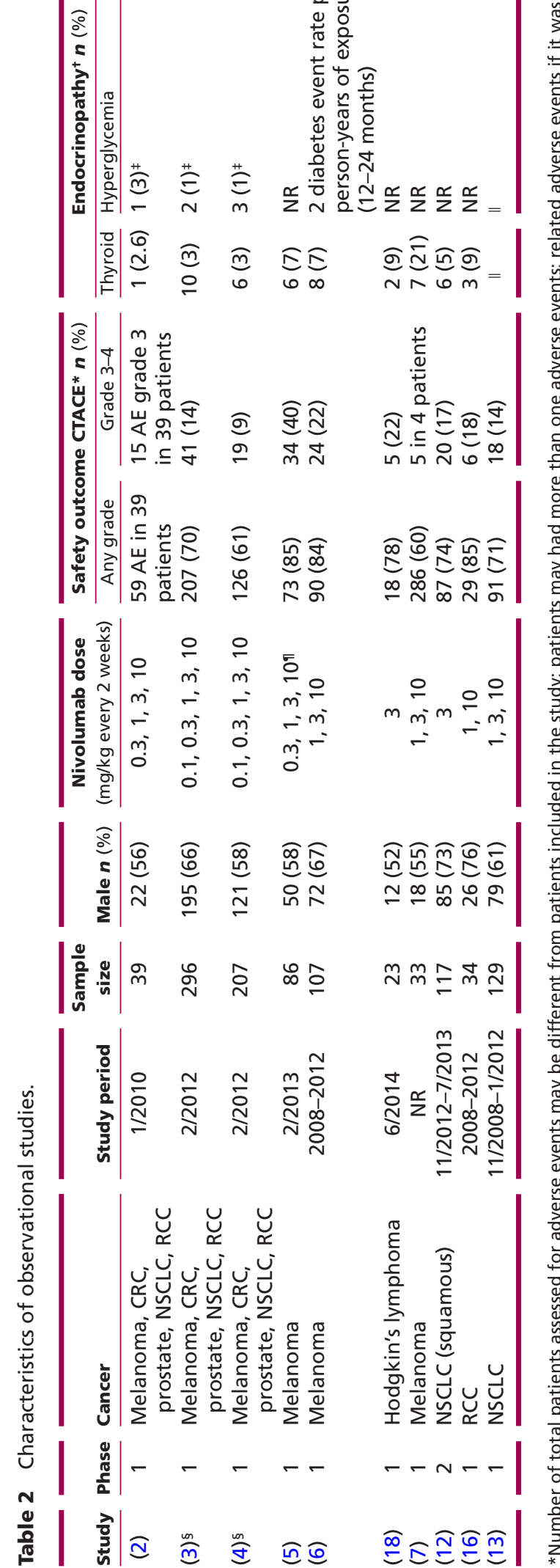

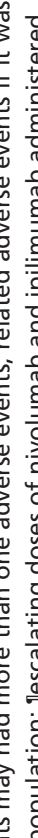

$\sim \infty$ ก

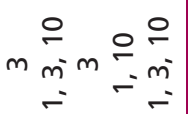

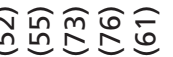

$\simeq \stackrel{\infty}{\circ} \stackrel{n}{\circ}$

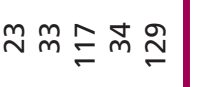

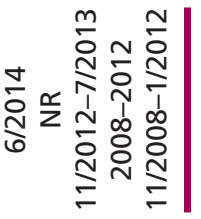

$\cup \quad \cup \quad u$

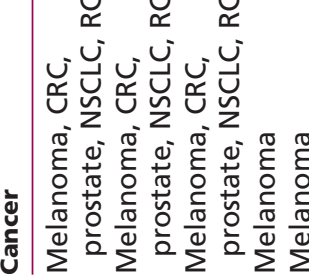

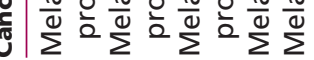

岁

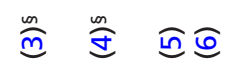

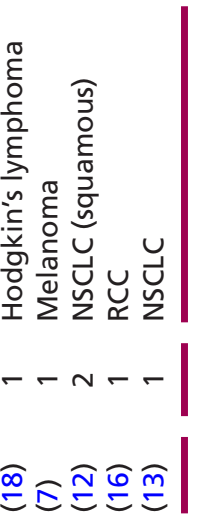

proximal post-nivolumab development of hyperglycemia, diabetes and glycation of hemoglobin. In all, this affirms the causal relationship between nivolumab and the newonset DM presenting as DKA in our patient.

We performed an extensive literature search of Medline database through February 2018 to identify all published case reports of anti-PD-1-induced DM. Search term used was nivolumab, pembrolizumab and ipilimumab. For each report, we extracted age, gender, cancer type, nature and time frame of presentation, $\mathrm{HbA1c}$, presence of autoantibodies, prior or concurrent chemotherapeutics, systemic steroids use and whether anti-PD-1 therapy was resumed. Reports' references were screened and all pertinent case reports were added. Additionally, we had previously performed a comprehensive literature search to identify all published articles that have investigated the impact of nivolumab on patients with cancer. Search term used was nivolumab and limits applied were: human and English. We reviewed the title and abstract of each article for possible inclusion. Articles that explored the effect of nivolumab on patients with cancer were included. For each included study, the information extracted included cancer type, study period, study design, sample size, gender, nivolumab dose, AE including common terminology criteria for adverse events (CTCAE) grade 3 or 4, and specifically, rates of endocrinopathy. Published manuscripts and supplemental materials were reviewed thoroughly for rates of treatment-related AE. Data about AE of any grade and of grade 3 or higher were gathered. Rates of thyroid disease, hypothyroidism and/or hyperthyroidism, were registered. Rates of hyperglycemia and rates of DM diagnosis, if reported, were also assembled and presented in tabular format. Our literature search produced 155 potential literature citations. After reviewing studies' title and/or abstract, a total of 17 studies were included (details are outlined in Tables 2 and 3).

Multiple trials have reported hyperglycemia as a potential $\mathrm{AE}$ with estimated risks of $0.5-11 \%$ (details are outlined in Tables 2 and 3). However, only three studies have reported on the outcome of formally diagnosed DM. An observational study by Topalian et al. (6) reported a rate of 2 cases of DM per 100 person-years of exposure with all cases being diagnosed after the first year of therapy. A randomized controlled trial (RCT) by Robert et al. (8) reported 1 case of DM in 206 melanoma patients. Another RCT by Borghaei et al. (15) reported 13 cases of hyperglycemia in 287 patients with non-squamous NSCLC but none were diagnosed with DM. None of the studies reported if hyperglycemia cases presented with DKA. There has been a growing number of case reports of 

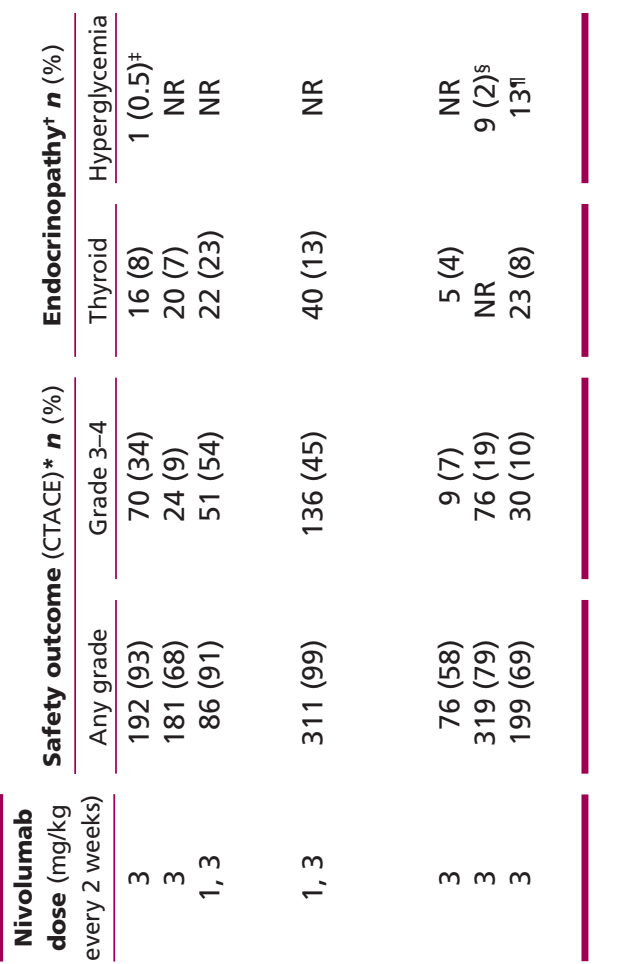

อิำ 要
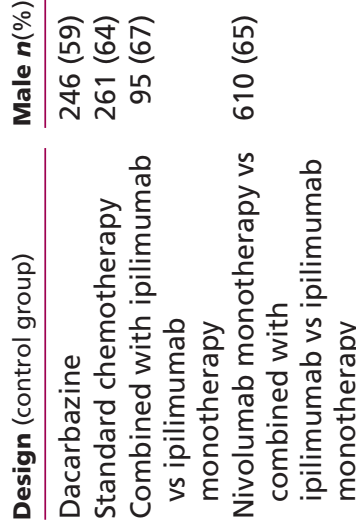

$\stackrel{m}{=}$

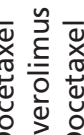

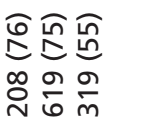
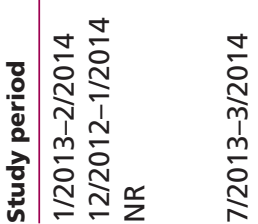

$m \frac{m}{\circ} \frac{m}{0}$

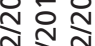

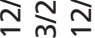
1) o. 으을
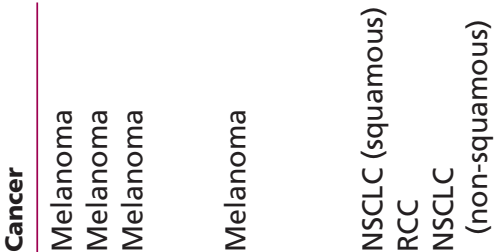

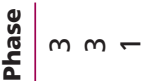

$z \propto z$

$m m m$

m

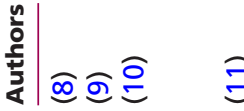

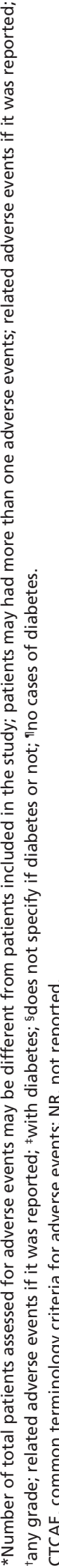

patients diagnosed with autoimmune diabetes following anti-PD-1 therapy. A comprehensive characteristic of these cases is summarized in Table 4. We have identified 42 cases of anti-PD-1-induced DM. The mean age is 61 years. There is no apparent gender or cancer preference though most cases were reported in patients with melanoma and NSCLC. Almost two-thirds of cases presented with DKA and within a time frame ranging from 1 week up to 1 year. About half of the cases had negative autoantibody serologies. Only two cases $(20,21)$ received systemic steroids specifically for pembrolizumab-induced DM. However, neither showed improvement nor resolution of DM. Half of the cases, resumed anti-PD-1 therapy after resolution of DKA or control of hyperglycaemia without further deterioration in DM control. Interestingly, we found two cases $(22,23)$ of autoimmune DM in patients with melanoma who received ipilimumab monotherapy (a human cytotoxic T-lymphocyte antigen 4 (CTLA-4)blocking antibody).

Immunotherapy in general, and nivolumab in specific, has revolutionized cancer therapy, and their use is rapidly growing. Consequently, the number of patients exposed to nivolumab will increase and the total number of patients experiencing AE will expectedly increase (24).

AEs during nivolumab treatment are frequent and range from $40 \%$ to $98 \%$. Most commonly, they include fatigue, rash, itching, diarrhea and infusion site reactions. They are largely managed by symptomatic and supportive care (25). The severe AEs (CTCAE grade 3 or 4) are estimated to occur between $5 \%$ and $72 \%$.They include pneumonitis, hepatitis and cytopenias. They are typically managed by discontinuing nivolumab and administering systemic corticosteroids $(2,25)$. Limited data noted suggest treating nivolumab-induced autoimmune DM are unlikely to be effective once DM has developed, and better understanding of why some individuals develop this complication is required before potential therapeutic and even preventative interventions might be identified.

The PD-1 pathway plays a central role in the regulation of autoimmune diabetes (26). Blockade of PD-1 can precipitate type 1 diabetes in mice models across all ages (27) and mechanisms may involve both humoral and cellular autoimmunity (19). However, there remain significant gaps in understanding the interaction between PD-1 pathway and autoimmune diabetes. Sparse data are available regarding the time course, dose relationship, effect of concurrent immunotherapeutic or chemotherapeutic agents and management (e.g. immunomodulatory agents). Despite being an uncommon $\mathrm{AE}$, developing irreversible insulin-dependent $\mathrm{DM}$ is life 


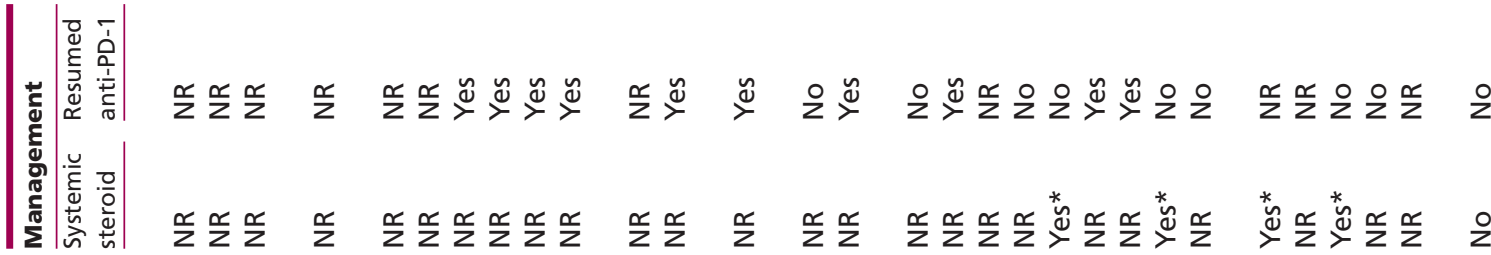

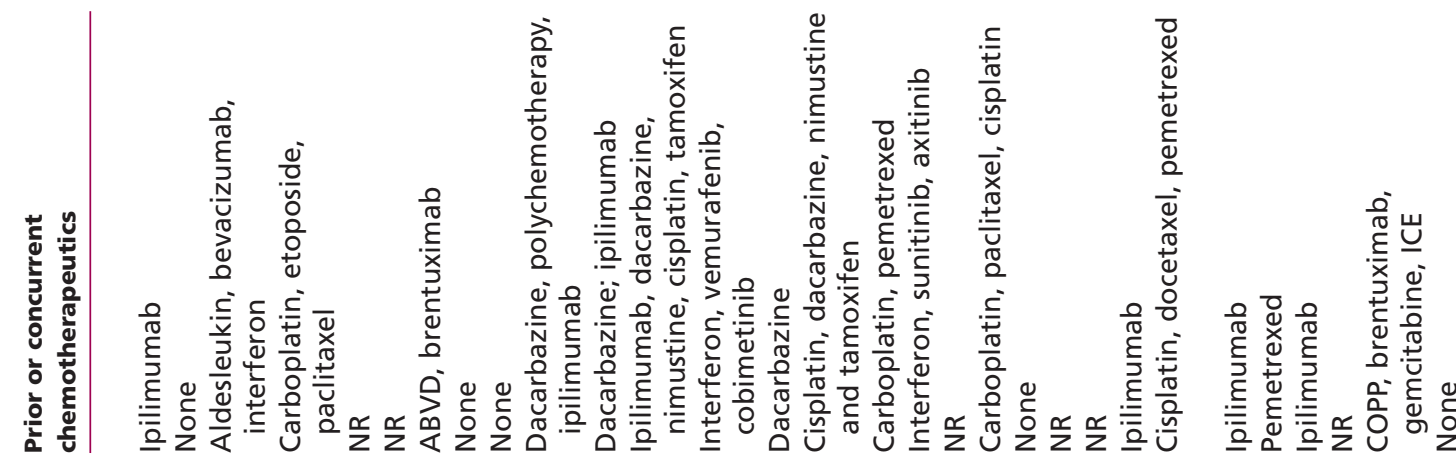

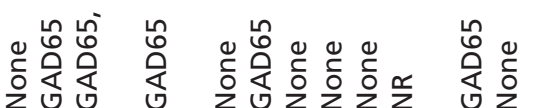
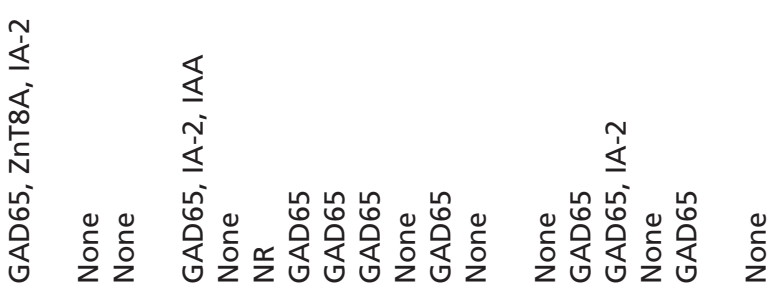

ดูก

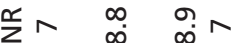

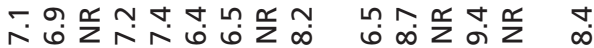
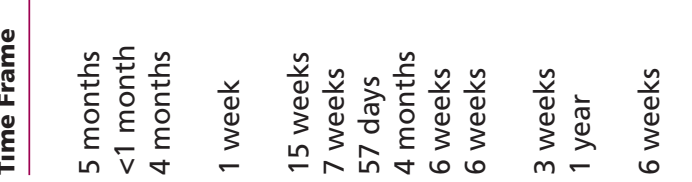

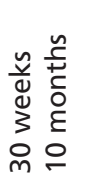
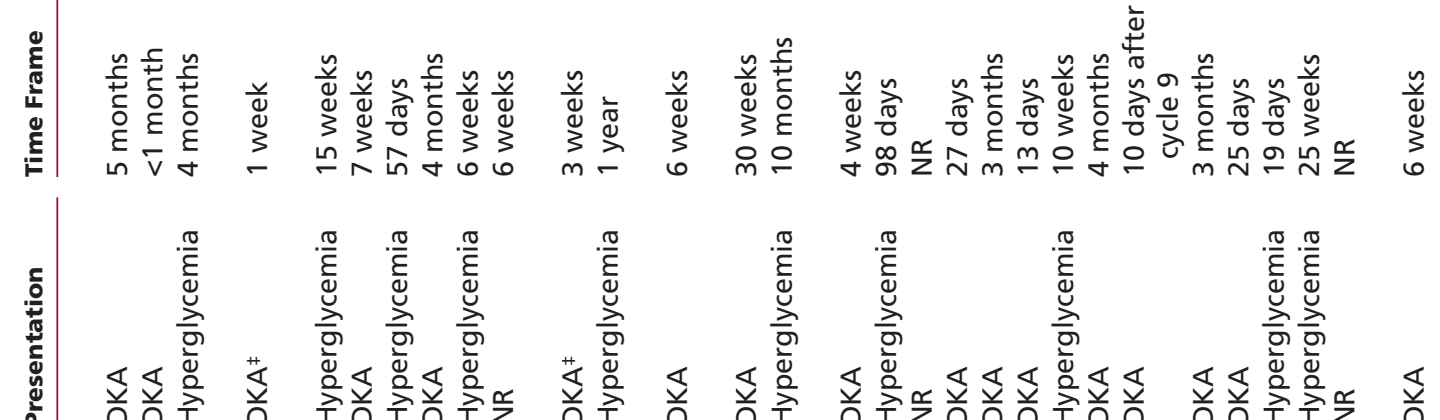

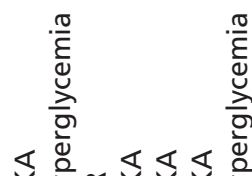

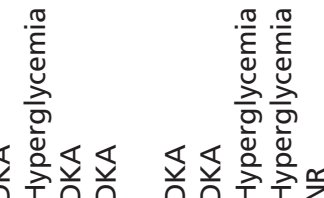<smiles>C1=[Se]C=[Se]C1</smiles><smiles>CCC</smiles><smiles>[SiH3]</smiles> 


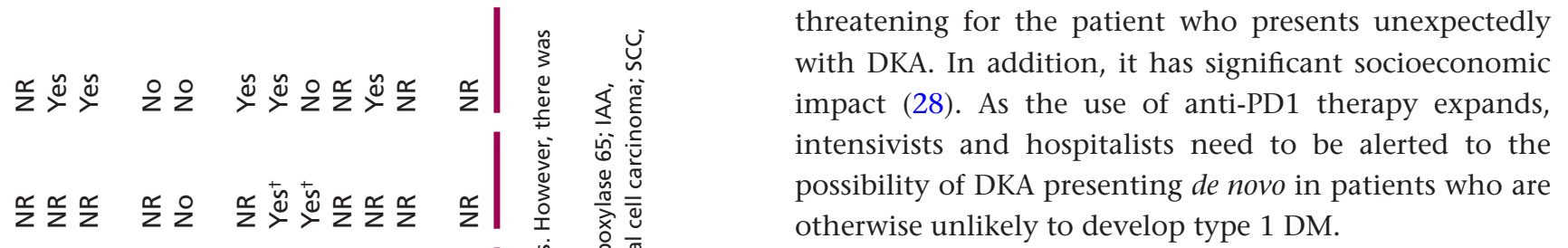

Declaration of interest

A A Z, H K A, R W J and A S L declare that there is no conflict of interest, proprietary or financial, regarding the publication of this report.

\section{Funding}

This research did not receive any specific grant from any funding agency in the public, commercial or not-for-profit sector.

\section{Patient consent}

Patient is now deceased and next of kin could not be traced.

\begin{abstract}
Author contribution statement
A A Z was responsible for the literature review and in the primary writing of the manuscript. $\mathrm{H} \mathrm{K} \mathrm{A}$ was the endocrinologist who was involved in the care of the patient's new diabetes and contributed expertise on the field of drug-induced autoimmune diabetes. $\mathrm{R} \mathrm{W} \mathrm{J} \mathrm{was} \mathrm{the} \mathrm{patient's} \mathrm{primary}$ oncologist and provided expertise on the mechanism of nivolumab and its contribution to autoimmune disorders. A S L was the intensivist in the care of the patient presenting with new-onset diabetic ketoacidosis and provided oversight on the writing and preparation of the manuscript.
\end{abstract}

\section{References}

1 Ribas A. Tumor immunotherapy directed at PD-1. New England Journal of Medicine 2012366 2517-2519. (https://doi.org/10.1056/ NEJMe1205943)

2 Brahmer JR, Drake CG, Wollner I, Powderly JD, Picus J, Sharfman WH, Stankevich E, Pons A, Salay TM, McMiller TL, et al. Phase I study of single-agent anti-programmed death-1 (MDX-1106) in refractory solid tumors: safety, clinical activity, pharmacodynamics, and immunologic correlates. Journal of Clinical Oncology 201028 3167-3175. (https://doi.org/10.1200/ JCO.2009.26.7609)

3 Topalian SL, Hodi FS, Brahmer JR, Gettinger SN, Smith DC, McDermott DF, Powderly JD, Carvajal RD, Sosman JA, Atkins MB, et al. Safety, activity, and immune correlates of anti-PD-1 antibody in cancer. New England Journal of Medicine 2012366 2443-2454. (https://doi.org/10.1056/NEJMoa1200690)

4 Brahmer JR, Tykodi SS, Chow LQM, Hwu WJ, Topalian SL, Hwu P, Drake CG, Camacho LH, Kauh J, Odunsi K, et al. Safety and activity of anti-PD-L1 antibody in patients with advanced cancer. New England Journal of Medicine 2012366 2455-2465. (https://doi. org/10.1056/NEJMoa1200694)

5 Wolchok JD, Kluger H, Callahan MK, Postow MA, Rizvi NA, Lesokhin AM, Segal NH, Ariyan CE, Gordon RA, Reed K, et al. Nivolumab plus ipilimumab in advanced melanoma. New England Journal of Medicine 2013369 122-133. (https://doi.org/10.1056/ NEJMoa1302369) 
6 Topalian SL, Sznol M, McDermott DF, Kluger HM, Carvajal RD, Sharfman WH, Brahmer JR, Lawrence DP, Atkins MB, Powderly JD, et al. Survival, durable tumor remission, and long-term safety in patients with advanced melanoma receiving nivolumab. Journal of Clinical Oncology 201432 1020-1030. (https://doi.org/10.1200/ JCO.2013.53.0105)

7 Gibney GT, Kudchadkar RR, DeConti RC, Thebeau MS, Czupryn MP, Tetteh L, Eysmans C, Richards A, Schell MJ, Fisher KJ, et al. Safety, correlative markers, and clinical results of adjuvant nivolumab in combination with vaccine in resected high-risk metastatic melanoma. Clinical Cancer Research 201521 712-720. (https://doi. org/10.1158/1078-0432.CCR-14-2468)

8 Robert C, Long GV, Brady B, Dutriaux C, Maio M, Mortier L, Hassel JC, Rutkowski P, McNeil C, Kalinka-Warzocha E, et al. Nivolumab in previously untreated melanoma without BRAF mutation. New England Journal of Medicine 2015372 320-330. (https://doi.org/10.1056/NEJMoa1412082)

9 Weber JS, D'Angelo SP, Minor D, Hodi FS, Gutzmer R, Neyns B, Hoeller C, Khushalani NI, Miller WH, Lao CD, et al. Nivolumab versus chemotherapy in patients with advanced melanoma who progressed after anti-CTLA-4 treatment (CheckMate 037): a randomised, controlled, open-label, phase 3 trial. Lancet Oncology 201516 375-384. (https://doi.org/10.1016/S1470-2045(15)70076-8)

10 Postow MA, Chesney J, Pavlick AC, Robert C, Grossmann K, McDermott D, Linette GP, Meyer N, Giguere JK, Agarwala SS, et al. Nivolumab and ipilimumab versus ipilimumab in untreated melanoma. New England Journal of Medicine 2015372 2006-2017. (https://doi.org/10.1056/NEJMoa1414428)

11 Larkin J, Chiarion-Sileni V, Gonzalez R, Grob JJ, Cowey CL, Lao CD, Schadendorf D, Dummer R, Smylie M, Rutkowski P, et al. Combined nivolumab and ipilimumab or monotherapy in untreated melanoma. New England Journal of Medicine 2015373 23-34. (https:// doi.org/10.1056/NEJMoa1504030)

12 Rizvi NA, Mazières J, Planchard D, Stinchcombe TE, Dy GK, Antonia SJ, Horn L, Lena H, Minenza E, Mennecier B, et al. Activity and safety of nivolumab, an anti-PD-1 immune checkpoint inhibitor, for patients with advanced, refractory squamous nonsmall-cell lung cancer (CheckMate 063): a phase 2, single-arm trial. Lancet Oncology 201516 257-265. (https://doi.org/10.1016/S14702045(15)70054-9)

13 Gettinger SN, Horn L, Gandhi L, Spigel DR, Antonia SJ, Rizvi NA Powderly JD, Heist RS, Carvajal RD, Jackman DM, et al. Overall survival and long-term safety of nivolumab (anti-programmed death 1 antibody, BMS-936558, ONO-4538) in patients with previously treated advanced non-small-cell lung cancer. Journal of Clinical Oncology 201533 2004-2012. (https://doi.org/10.1200/ JCO.2014.58.3708)

14 Brahmer J, Reckamp KL, Baas P, Crinò L, Eberhardt WEE, Poddubskaya E, Antonia S, Pluzanski A, Vokes EE, Holgado E, et al. Nivolumab versus docetaxel in advanced squamous-cell non-smallcell lung cancer. New England Journal of Medicine 2015373 123-135. (https://doi.org/10.1056/NEJMoa1504627)

15 Borghaei H, Paz-Ares L, Horn L, Spigel DR, Steins M, Ready NE, Chow LQ, Vokes EE, Felip E, Holgado E, et al. Nivolumab versus docetaxel in advanced nonsquamous non-small-cell lung cancer. New England Journal of Medicine 2015373 1627-1639. (https://doi. org/10.1056/NEJMoa1507643)

16 McDermott DF, Drake CG, Sznol M, Choueiri TK, Powderly JD, Smith DC, Brahmer JR, Carvajal RD, Hammers HJ, Puzanov I, et al. Survival, durable response, and long-term safety in patients with previously treated advanced renal cell carcinoma receiving nivolumab. Journal of Clinical Oncology 201533 2013-2020. (https:// doi.org/10.1200/JCO.2014.58.1041)

17 Motzer RJ, Escudier B, McDermott DF, George S, Hammers HJ, Srinivas S, Tykodi SS, Sosman JA, Procopio G, Plimack ER, et al. Nivolumab versus everolimus in advanced renal-cell carcinoma.
New England Journal of Medicine 2015373 1803-1813. (https://doi. org/10.1056/NEJMoa1510665)

18 Ansell SM, Lesokhin AM, Borrello I, Halwani A, Scott EC, Gutierrez M, Schuster SJ, Millenson MM, Cattry D, Freeman GJ, et al. PD-1 blockade with nivolumab in relapsed or refractory Hodgkin's lymphoma. New England Journal of Medicine 2015372 311-319. (https://doi.org/10.1056/NEJMoa1411087)

19 Hughes J, Vudattu N, Sznol M, Gettinger S, Kluger H, Lupsa B \& Herold KC. Precipitation of autoimmune diabetes with anti-PD-1 immunotherapy. Diabetes Care 201538 e55-e57. (https://doi. org/10.2337/dc14-2349)

20 Aleksova J, Lau PKH, Soldatos G \& McArthur G. Glucocorticoids did not reverse type 1 diabetes mellitus secondary to pembrolizumab in a patient with metastatic melanoma. BMJ Case Reports 20162016. (https://doi.org/10.1136/bcr-2016-217454)

21 Chae YK, Chiec L, Mohindra N, Gentzler R, Patel J \& Giles F. A case of pembrolizumab-induced type- 1 diabetes mellitus and discussion of immune checkpoint inhibitor-induced type 1 diabetes. Cancer Immunology, Immunotherapy 201766 25-32. (https://doi.org/10.1007/ s00262-016-1913-7)

22 Jørgensen LB \& Yderstræde K. Acutely induced diabetes mellitus in a 63-year-old female after treatment with ipilimumab for metastatic melanoma. Ugeskrift for Laeger 2017179 V03170188.

23 Tsiogka A, Jansky GL, Bauer JW \& Koelblinger P. Fulminant type 1 diabetes after adjuvant ipilimumab therapy in cutaneous melanoma. Melanoma Research 201727 524-525. (https://doi.org/10.1097/ CMR.0000000000000384)

24 Haanen JBAG, van Thienen H \& Blank CU. Toxicity patterns with immunomodulating antibodies and their combinations. Seminars in Oncology 201542 423-428. (https://doi.org/10.1053/j. seminoncol.2015.02.011)

25 Barbee MS, Ogunniyi A, Horvat TZ \& Dang TO. Current status and future directions of the immune checkpoint inhibitors ipilimumab, pembrolizumab, and nivolumab in oncology. Annals of Pharmacotherapy 201549 907-937. (https://doi. org/10.1177/1060028015586218)

26 Ansari MJI, Salama AD, Chitnis T, Smith RN, Yagita H, Akiba H, Yamazaki T, Azuma M, Iwai H, Khoury SJ, et al. The programmed death-1 (PD-1) pathway regulates autoimmune diabetes in nonobese diabetic (NOD) mice. Journal of Experimental Medicine 2003198 63-69. (https://doi.org/10.1084/jem.20022125)

27 Guleria I, Gubbels Bupp M, Dada S, Fife B, Tang Q, Ansari MJ, Trikudanathan S, Vadivel N, Fiorina P, Yagita H, et al. Mechanisms of PDL1-mediated regulation of autoimmune diabetes. Clinical Immunology 2007125 16-25. (https://doi.org/10.1016/j. clim.2007.05.013)

28 Gosmanov AR, Gosmanova EO \& Dillard-Cannon E. Management of adult diabetic ketoacidosis. Diabetes, Metabolic Syndrome and Obesity: Targets and Therapy 20147 255-264. (https://doi.org/10.2147/DMSO. S50516)

29 Mellati M, Eaton KD, Brooks-Worrell BM, Hagopian WA, Martins R, Palmer JP \& Hirsch IB. Anti-PD-1 and anti-PDL-1 monoclonal antibodies causing type 1 diabetes. Diabetes Care 201538 e137-e138. (https://doi.org/10.2337/dc15-0889)

30 Munakata W, Ohashi K, Yamauchi N \& Tobinai K. Fulminant type I diabetes mellitus associated with nivolumab in a patient with relapsed classical Hodgkin lymphoma. International Journal of Hematology 2017105 383-386. (https://doi.org/10.1007/s12185-0162101-4)

31 Miyoshi Y, Ogawa O \& Oyama Y. Nivolumab, an anti-programmed cell death-1 antibody, induces fulminant type 1 diabetes. Tohoku Journal of Experimental Medicine 2016239 155-158. (https://doi. org/10.1620/tjem.239.155)

32 Hofmann L, Forschner A, Loquai C, Goldinger SM, Zimmer L, Ugurel S, Schmidgen MI, Gutzmer R, Utikal JS, Göppner D, et al. Cutaneous, gastrointestinal, hepatic, endocrine, and renal side- 
effects of anti-PD-1 therapy. European Journal of Cancer $2016 \mathbf{6 0}$ 190-209. (https://doi.org/10.1016/j.ejca.2016.02.025)

33 Okamoto M, Okamoto M, Gotoh K, Masaki T, Ozeki Y, Ando H, Anai M, Sato A, Yoshida Y, Ueda S, et al. Fulminant type 1 diabetes mellitus with anti-programmed cell death-1 therapy. Journal of Diabetes Investigation 20167 915-918. (https://doi.org/10.1111/ jdi.12531)

34 Gauci ML, Laly P, Vidal-Trecan T, Baroudjian B, Gottlieb J, Madjlessi-Ezra N, Da Meda L, Madelaine-Chambrin I, Bagot M, Basset-Seguin N, et al. Autoimmune diabetes induced by PD-1 inhibitor-retrospective analysis and pathogenesis: a case report and literature review. Cancer Immunology, Immunotherapy 201766 1399-1410. (https://doi.org/10.1007/s00262-017-2033-8)

35 Teramoto Y, Nakamura Y, Asami Y, Imamura T, Takahira S, Nemoto M, Sakai G, Shimada A, Noda M \& Yamamoto A. Case of type 1 diabetes associated with less-dose nivolumab therapy in a melanoma patient. Journal of Dermatology 201744 605-606. (https:// doi.org/10.1111/1346-8138.13486)

36 Ishikawa K, Shono-Saito T, Yamate T, Kai Y, Sakai T, Shimizu F, Yamada Y, Mori H, Noso S, Ikegami H, et al. A case of fulminant type 1 diabetes mellitus, with a precipitous decrease in pancreatic volume, induced by nivolumab for malignant melanoma: analysis of HLA and CTLA-4 polymorphisms. European Journal of Dermatology 201727 184-185. (https://doi.org/10.1684/ejd.2016.2923)

37 Godwin JL, Jaggi S, Sirisena I, Sharda P, Rao AD, Mehra R \& Veloski C. Nivolumab-induced autoimmune diabetes mellitus presenting as diabetic ketoacidosis in a patient with metastatic lung cancer. Journal for Immunotherapy of Cancer 20175 40. (https://doi. org/10.1186/s40425-017-0245-2)

38 Sakurai K, Niitsuma S, Sato R, Takahashi K \& Arihara Z. Painless thyroiditis and fulminant type 1 diabetes mellitus in a patient treated with an immune checkpoint inhibitor, nivolumab. Tohoku Journal of Experimental Medicine 2018244 33-40. (https://doi. org/10.1620/tjem.244.33)

39 Araújo M, Ligeiro D, Costa L, Marques F, Trindade H, Correia JM \& Fonseca C. A case of fulminant Type 1 diabetes following anti-PD1 immunotherapy in a genetically susceptible patient. Immunotherapy 20179 531-535. (https://doi.org/10.2217/imt-2017-0020)

40 Li L, Masood A, Bari S, Yavuz S \& Grosbach AB. Autoimmune diabetes and thyroiditis complicating treatment with nivolumab. Case Reports in Oncology 201710 230-234. (https://doi. org/10.1159/000456540)

41 Kapke J, Shaheen Z, Kilari D, Knudson P \& Wong S. Immune checkpoint inhibitor-associated type 1 diabetes mellitus: case series, review of the literature, and optimal management. Case Reports in Oncology 201710 897-909. (https://doi.org/10.1159/000480634)

42 Usui Y, Udagawa H, Matsumoto S, Imai K, Ohashi K, Ishibashi M, Kirita K, Umemura S, Yoh K, Niho S, et al. Association of serum anti-GAD antibody and HLA haplotypes with type 1 diabetes mellitus triggered by nivolumab in patients with non-small cell lung cancer. Journal of Thoracic Oncology 201712 e41-e43. (https://doi. org/10.1016/j.jtho.2016.12.015)

43 Lowe JR, Perry DJ, Salama AKS, Mathews CE, Moss LG \& Hanks BA. Genetic risk analysis of a patient with fulminant autoimmune type 1 diabetes mellitus secondary to combination ipilimumab and nivolumab immunotherapy. Journal for Immunotherapy of Cancer 2016 4 89. (https://doi.org/10.1186/s40425-016-0196-z)

44 Marchand L, Paulus V, Fabien N, Pérol M, Thivolet C, Vouillarmet J \& Saintigny P. Nivolumab-induced acute diabetes mellitus and hypophysitis in a patient with advanced pulmonary pleomorphic carcinoma with a prolonged tumor response. Journal of Thoracic Oncology 201712 e182-e184. (https://doi.org/10.1016/j. jtho.2017.07.021)

45 Changizzadeh PN, Mukkamalla SKR \& Armenio VA. Combined checkpoint inhibitor therapy causing diabetic ketoacidosis in metastatic melanoma. Journal for Immunotherapy of Cancer 2017597. (https://doi.org/10.1186/s40425-017-0303-9)

46 Capitao R, Bello C, Fonseca R \& Saraiva C. New onset diabetes after nivolumab treatment. BMJ Case Reports 2018 2018. (https://doi. org/10.1136/bcr-2017-220999)

47 Villarreal J, Townes D, Vrablik M \& Ro K. A case of drug-induced severe endocrinopathies: what providers in the emergency department need to know. Advanced Emergency Nursing Journal 2018 40 16-20. (https://doi.org/10.1097/TME.0000000000000173)

48 Kumagai R, Muramatsu A, Nakajima R, Fujii M, Kaino K, Katakura Y, Okumura N, Ohara G, Kagohashi K, Satoh H, et al. Acute-onset type 1 diabetes mellitus caused by nivolumab in a patient with advanced pulmonary adenocarcinoma. Journal of Diabetes Investigation $2017 \mathbf{8}$ 798-799. (https://doi.org/10.1111/jdi.12627)

49 Chang E, Rivero G, Patel NR, Chiao EY, Lai S, Bajaj K, Mbue JE \& Yellapragada SV. HIV-related refractory Hodgkin lymphoma: a case report of complete response to nivolumab. Clinical Lymphoma, Myeloma and Leukemia 201818 e143-e146. (https://doi. org/10.1016/j.clml.2017.12.008)

50 Martin-Liberal J, Furness AJ, Joshi K, Peggs KS, Quezada SA \& Larkin J. Anti-programmed cell death-1 therapy and insulindependent diabetes: a case report. Cancer Immunology, Immunotherapy 201564 765-767. (https://doi.org/10.1007/s00262-015-1689-1)

51 Gaudy C, Clévy C, Monestier S, Dubois N, Préau Y, Mallet S, Richard MA, Grob JJ, Valéro R \& Béliard S. Anti-PD1 pembrolizumab can induce exceptional fulminant type 1 diabetes. Diabetes Care 2015 38 e182-e183. (https://doi.org/10.2337/dc15-1331)

52 Humayun MA \& Poole R. A case of multiple immune toxicities from Ipilimumab and pembrolizumab treatment. Hormones 201615 303-306. (https://doi.org/10.14310/horm.2002.1656)

53 Hansen E, Sahasrabudhe D \& Sievert L. A case report of insulindependent diabetes as immune-related toxicity of pembrolizumab: presentation, management and outcome. Cancer Immunology, Immunotherapy 201665 765-767. (https://doi.org/10.1007/s00262016-1835-4)

54 Mizab Mellah C, Sánchez Pérez M, Santos Rey MD \& Hernández García M. Fulminant type 1 diabetes mellitus associated with pembrolizumab. Endocrinologia, Diabetes y Nutricion 201764 272-273. (https://doi.org/10.1016/j.endinu.2017.01.005)

55 Leonardi GC, Oxnard GR, Haas A, Lang JP, Williams JS \& Awad MM. Diabetic ketoacidosis as an immune-related adverse event from pembrolizumab in non-small cell lung cancer. Journal of Immunotherapy 201740 249-251. (https://doi.org/10.1097/ CJI.0000000000000173)

56 Smith-Cohn MA, Gill D, Voorhies BN, Agarwal N \& GarridoLaguna I. Case report: pembrolizumab-induced Type 1 diabetes in a patient with metastatic cholangiocarcinoma. Immunotherapy 20179 797-804. (https://doi.org/10.2217/imt-2017-0042)

57 Scott ES, Long GV, Guminski A, Clifton-Bligh RJ, Menzies AM \& Tsang VH. The spectrum, incidence, kinetics and management of endocrinopathies with immune checkpoint inhibitors for metastatic melanoma. European Journal of Endocrinology 2018178 175-182. (https://doi.org/10.1530/EJE-17-0810)

Received in final form 19 February 2018

Accepted 2 March 2018 